трагедії. Ймовірний зворотний відлік до потрібного людській свідомості щасливого розв'язання історії чи зумовлена психікою сучасного «Я» потреба «досягнути дна» і таким чином знайти опору/трамплін особливість аналітичної структури сучасного роману полягає, на наш погляд, у тому, що він становить своєрідний «початок координат», «нуль», який дає невичерпні можливості до трактувань, серед яких, однак, лише одне $\epsilon$ істинним. Відтак, читач метамодерністичного твору, перегортаючи першу сторінку, «вплутується» в художню авантюру, стає на такий-собі шлях пошуку філософського каменя, де безліч «всеможливих смислів» творять аксіологічно-гносеологічну парадигму.

\title{
Література:
}

1. Барт P. S/Z. Москва : Эдиториал УРCC, 2001. 232 с.

2. Гиршман М. Литературное произведение: теория художественной целостности. Москва : Языки славянской культуры, 2002. 560 с.

3. Зубрицька M. Homo legens : читання як соціокультурний феномен. Львів : Літопис, 2004. 352 с.

4. Мітосек 3. Теорії літературних досліджень / пер. 3 пол. В. Гуменюк ; наук. ред. В. Іванюк. Сімферополь : Таврія, 2005. 407 с.

5. Фоер Дж. С. Страшенно голосно і неймовірно близько / пер. з англ. О. Постранської. Харків : Клуб сімейного дозвілля, 2015. 384 с.

DOI https://doi.org/10.30525/978-9934-26-180-0-10

\section{СЕМАНТИЧНА ТА ФУНКЦІОНАЛЬНА ХАРАКТЕРИСТИКА СТИЛІСТИЧНО-МАРКОВАНОЇ ЛЕКСИКИ ІСТОРИЧНОЇ ПРОЗИ БОГДАНА ЛЕПКОГО}

\author{
Михайленко В. В.
}

кандидат філологічних наук,

старший викладач кафедри зарубіжної літератури та основ риторики

Комунальний заклад вищої освіти

«Вінницький гуманітарно-педагогічний коледж»

м. Вінниця, Украӥна

Вживання діалектизмів зі стилістичною метою пов'язане з естетичнохудожньою функцією мови. Так, у сучасних художніх творах основна їхня функція полягає в тому, «...що письменник, вживаючи діалектні елементи 
рідного йому говору чи наріччя у мові персонажів і авторській мові, свідомо чи несвідомо використовує їх замість слів літературної мови» [1, с. 39]. У час, коли писав свої історичні романи Б. Лепкий, чіткого функціонального протиставлення лексичних норм літературної мови i норм усно-розмовного, діалектного спілкування не було. Більше того, історична тематика спонукала автора до використання із зображальновиражальною метою всіх лексичних ресурсів національної мови.

Обстежений матеріал засвідчує, що словник Б. Лепкого 3 погляду сучасної норми вирізняється активним використанням діалектної лексики. Обмежимося більш детальною характеристикою таких частин мови 3 вищезгаданими стилістичними позначками, як-от: іменники, прикметники та дієслова. Зазначаємо, що після лексем, зафіксованих в історичному творі Б. Лепкого, подаємо у лапках їхні тлумачення, наведені в 11-томному Словнику української мови.

В історичній прозі Богдана Лепкого виокремлюємо групу слів, що

супроводжуються у загальномовному словнику (СУМ в 11-ти т.) стилістичною ремаркою діал. Серед них розрізняємо: 1. іменники: алькир - «альков - заглиблення в стіні кімнати для ліжка, ніша», бараболя - «картопля», баришівник - «перекупник, перепродувач, людина, яка скуповує товар та перепродує його», бахмат - «бойовий верховий кінь», білля - «білизна», бочівка - «бочка, діжка», вареха - «ополоник», вдяка «вдячність», вітчина - «вітчизна», врем'я - «час», вугляр - «вугілля».

Серед діалектизмів розрізняємо такі тематичні групи лексики:

1) назви житлових і господарських будівель та їх частин, предметів домашнього побуту, знарядь праці: алькир, білля, бочівка, вареха, збан, клевець, кобеля, ланець, лани, маглівниця, окап, острокіл, пугар, робітня, сидження, склеп, скритка, стаднина, топір, улій, файка, фотель, чіп, шрубка: Хазяїн попросив його [Чечеля] в алькир, добув із-за образа вчетверо зложений лист паперу і сказав [3. с, 495]

2) назви людей за родом занять та суспільним становищем: баришівник, газдиня, зверхник, кухта, кухтик, молодіж, хазяй: - Тю!.. Або $я$ [чумак] що таке! Наймиток купецький чи баришівник жидівський [2. c, 152]

3) назви людей з відтінком зневаги: драб, лупій, сарака, шубравець: Я [осавул] саме над'їхав $і$ скипів: з пістоля поклав одного драба, шаблюкою двох зарубав, бо не сподівалися, а четвертий утік та дав своїм знати [2, с. 142]

4) назви спорідненості $\boldsymbol{i}$ свояцтва: сестринець, сестрінниця, сестрінка, швагер, напр.: Мотря, їі сестра Ганна Обидовська і гетьманів сестринець Войнаровський на замку зустрілися [2, с. 358] 
5) назви свійських тварин, птахів, звірів, комах: бахмат, звірик, кундель, куропатва, куря, падлина, соловій, чміль: Король на турецькому бахматі, гетьман у кареті, бо хорий, відділ яничарів з ними [2, с. 170].

6) реалії рослинного світу: бараболя, зільник, купчаки, мерва, чічка, шувар: - Йому [невольнику], щоб хліб і бараболя, а з якого вона поля, не дбає, - ̈стьь [2, с. 31]

7) назви предметів та явищ природи: живло, звізда, зимно, мокляк, сумерк, хабуз, яскиня: Так лютує і скаженіє тільки вода, прорвавши греблю, i пожар, вихопившися з тих меж, у які вложив його промисел людський, так скаженіє безумне й бездушне живло [2, с. 413]

8) назви понять часу: врем'я, триднівка: Коли було б гарне врем'я, то спочивали б у полі [2, с. 209]

9) предмети харчування: мід, омаста, риж, напр.: Замість срібних тарілок подали фарфорові з малюнками козаків $i$ коней біля шатер і крамів, у яких гарні шинкарки шинкували мід та горілку [2, с. 11]

10) назви хвороб: гостечь, хороба: - А ломив би їх [москалів] чорт та мняв би їх, як бабу гостець [2, с. 44]

11) назви понять, пов'язані з народною демонологісю: опир, хованець: Пригадує [офіцер] собі давно забуті казки про відьом і опирів $[2$, c. 420$]$

Серед зазначених діалектизмів виокремлюємо невелику групу абстрактних понять типу вдяка, далекосяглість, дивоглядія, ділання, жура, заглада, заклопотання, змора, колот, марниця, мус, невдяка, ошука, полегша, похіть, прочуття, хов, хосен, більшість з яких передають світ людських емоцій, переживань, психічного та фізичного стану людини: Тепер на вдяку людську не числи [3, с. 396]

Зафіксовані у досліджуваних текстах прикметники типу встеклий «скажений», гонорний «з гонором», дідьчий «дідьків», діточий «дитячий», догідний «який задовольняючи певні вимоги, може бути вживаний для чого-небудь, придатний на що-небудь», загарливий «запопадливий, запальний», загніваний «розгніваний», когутячий «прикм. до когут», лядський «ляський», напрасний «раптовий, несподіваний»,

Серед наведених прикметників виокремлюємо тематичні групи, що означають:

1) особливості характеру, вдачі, інтелекту і психічного стану людини: гонорний, загарливий, недовірчивий, робучий, статочний, напр.: - Ох, бо нинішні наші молоді достойники дуже в вамеці несуться, гонорні такі, щуо без бука й не приступай [3, с. 361] 
2) фізичні якості людини або тварини: встеклий, хорий, хоробливий, храпливий, хрупкий, напр.: Мручко зі своӥми людьми відганяв ïx [калмуків] від обозу, як встеклу тічню [3, с. 483]

3) ознаки предметів за ӥх зовнішніми особливостями: підраний, ховзкий, напр.: Між полоненими москалями несли на драбині, знятій з якогось воза, тяжко покаліченого козака, біля котрого ступала якась жінка в підранім тулубку $і$ кратястою хусткою, мов турецьким турбаном, обкручена так, що тільки двоє очей, чорних, як вуглики, світилося [3, с. 210]

Чималу групу діалектизмів становлять дісслова: багнути «прагнути до чого-небудь», баламкати «недбало махати», белендіти «базікати», виклинати «проклинати», виправити «виряджати кого-небудь кудись», витривати «витримати», виховзнутися «вислизати», вівкати «вигукувати звук», врадуватися «зрадіти», вставлятися «заступатися», гериювати «гарцювати», гибнути «гинути», гуторити «розмовляти», доглупатися «зрозуміти, збагнути», доглянути «побачити, помітити», дозирати «доглядати»

У межах вищезазначених лексем виокремлюємо такі семантичні групи:

1) розмови і мовлення: белендіти, вівкати, гуторити: - Іване Степановичу, - белендів [Кочубей] не своїм голосом [3, с. 294]

2) бачення: доглянути, дозирати, покмітити: Поміж робітниками доглянув гетьман здалеку молодого парубка, рослого $і$ здорового і такого гарного, щео тільки стій і дивися [3, с. 51]

3) фізичного стану: гибнути, знебутися: Пригадували собі, як иілі відділи кінниці перетворювалися в піхоту, бо коні гибли в тих одчайдушних перегонах з москалями [3, с. 13-14]

4) фізичного зусилля: мервити, потрутити, смарувати, струтити, трутити, тручати: Мервив і дер [москаль] його [волосся], не знати, чи з жалю, чи зі злості [3, с. 97]

5) наростання і спад ознаки: приспорити, прозябати, уйнятися, ияпотіти:- Приспорила вона [Мотря Василівна] тобі [Іване Степановичу] чимало турботи. От дівочі примхи [3, с. 349]

6) виявлення почуттів: врадуватися, падькатися, сторопитися: Запорожиі, побачивши далеко в степу куряву, думали, що ще надходять татари, котрих їм хан у допомогу прислати обічяв, і врадувалися дуже [3, c. 460-461]

7) взаємної дії та взаємозалежності: лучити, перечитися, правуватися: - А щзо лучить Мазепу і Карла? - Інтерес. Гадають, що їм по дорозі, і тому разом ідуть [3, с. 423] 
8) місцезнаходження та місцеположення: виховзнутися, гериювати, замешкувати, зміститися, розгоститися, спічнути, шульнути: - A пустиш чи дозволиш виховзнутися їм [старшинам i народу] 3-під меча Теміди, так скажуть: «Можна доносити на гетьмана. Не карає» [3, с.., 180]

9) захисту: вставлятися, уйматися: - Кажи, що важко недужсий Іван Степанович вставлясться за жінками й дітьми покійного Кочубея $i$ Іскри [2, с. 204]

Отже, аналіз лексичних одиниць зі стилістичною ремаркою діал. в історичній прозі Б. Лепкого дає змогу лексикографам поповнити згаданий словник відповідними лексемами і контекстами.

\section{Лiтература:}

1. Кліщун Г., Чорненький Я. Мовна ситуація в Україні кінця XIX початку XX століття. Українська мова: з минулого в майбутнє: Матеріали наукової конференції (12-14 лютого 1998 р. Київ). Київ. 1998. 39 с.

2. Лепкий Б. Не вбивай: Історична повість / упоряд. Р. Д. Горак. Київ: Дніпро, 1992. 262 с.

3. Лепкий Б. Твори: У 2 т. / упоряд., авт. вступ. статті та приміт. Ф. П. Погребенник. Київ: Наук. думка, 1997. Т. 1. 91 с. 